\title{
TANFELÜGYELET, SZAKFELÜGYELET ÉS A TANÁRI TELJESÍTMÉNY ÉRTÉKELÉSE ANGLIÁBAN
}

\author{
KIRÁLY ZSOLT \\ az Eötvös Loránd Tudományegyetem Bölcsészettudományi Karának \\ adjunktusa \\ kiraly.zsolt@btk.elte.hu
}

\begin{abstract}
Az alábbi tanulmány részletesen bemutatja a három pilléren nyugvó angol tan- és szakfelügyeleti rendszert, amely szemléletében és gyakorlatában sok szempontból lényegesen különbözik a bevezetés elött álló magyar felügyeleti rendszertöl. Ebben a rendszerben az egyes tanárok iskolai teljesítményértékelése az oktatási intézmények kötelezöen, éves ciklusokban végrehajtandó feladata, amely egy belsö értékelési rendszeren keresztül történik. A tanfelügyelet, amely az egész iskola és nem az egyes tanárok minösitését végzi, az Ofsted nevü, az Oktatási Minisztériumtól független kormányzati intézmény feladata, amelyet rendszeres felügyeleti látogatásokon keresztül, kötelezö jelleggel, ötévenkénti gyakorisággal hajt végre. A harmadik láb, amely reprezentatív mintán végzett, szakfelügyeleti, azaz tantárgyi vagy tematikus vizsgálatokat jelent, teljesen elkülönül a tanfelügyelettöl, és szintén az egész iskola és nem az egyes tanárok teljesitményét vizsgálja.
\end{abstract}

\section{Bevezetés}

A mai magyar kormányzat által deklarált célnak többnyire megfelelö, de a hazai köztudatban élő képtől alapvetően különböző tanfelügyeleti szisztéma Angliában már mintegy 180 éve működik, természetesen az idők során más-más szervezeti rendszerben és különböző hangsúlyokkal (Sinka, 2008). A különbség lényege úgy foglalható össze, hogy az angol rendszerben a vizsgált iskolák összteljesítményének minősítése (tanfelügyelet), az egyes pedagógusok munkájának értékelése (teljesitményértékelés) és a szaktárgyi felügyelet (szakfelügyelet) élesen elkülönülnek egymástól. Olyannyira így van ez, hogy (az írás, olvasás és matematikai ismeretek kivételével) az egyes tantárgyakról alig történik említés a tanfelügyeleti jelentésekben, valamint egyrészt tilos az egyes tanárok puszta megnevezése is, másrészt pedig a tanfelügyelőknek átadott belső, iskolai teljesítményvizsgálati eredményekben sem szabad névvel szerepeltetni senkit. Más megfogalmazásban: Angliában a kormány fenntartja magának a jogot arra, hogy ellenőrizze, hogy az iskolák megfelelnek-e az elvárt követelményeknek, valamint biztosítja a tantárgyak szakszerü tanításának szakmai felügyeletét is, de az egyes tanárok teljesítményének megítélését magukra az iskolára bízza. 
A mai angol rendszer tehát három pilléren nyugszik: az iskolai teljesitményértékelés az oktatási intézmények kötelezően, éves ciklusokban végrehajtandó feladata, amely egy belső értékelési rendszeren keresztül történik, a tanfelügyelet az Ofsted nevü, az Oktatási Minisztériumtól független kormányzati intézmény feladata, amelyet rendszeres felügyeleti látogatásokon keresztül, kötelező jelleggel, (alapesetben) ötévenkénti gyakorisággal hajt végre. A harmadik láb, amely reprezentatív mintán végzett, szakfelügyeleti, azaz tantárgyi vagy egyéb pedagógiai tárgyú tematikus vizsgálatokat jelent, 2005 óta egyre erőteljesebben (2011-2012 óta pedig szinte teljesen) elkülönül a tanfelügyelettől, szintén az Ofsted hatáskörébe tartozik.

Mivel Magyarországon sokan a szakfelügyelet fő funkciójának a tanárok fegyelmezését és tisztességes munkára való kényszerítését gondolják, meg kell jegyezni, hogy a munkáltató (az igazgató és az iskolafenntartó) hatáskörébe tartozó problémákat és fegyelmi kérdéseket - természetesen - maga a munkaadó bírálja el a munkaköri leírás, illetve az iskola saját fegyelmi szabályzata alapján, míg a súlyos, kriminális vagy annak gyanújával terhelt esetek (adott esetben a rendőrségen kívül) az Oktatási Ügynökség (Teaching Agency) nevü kormányhivatal elé kerülnek. A részeg vagy a diákjait zaklató tanár esetével tehát a felügyelet csak akkor foglalkozik, ha véletlenül ők hallanak a dologról először, és ilyenkor is mindössze csak továbbítják az információkat az illetékes szervekhez (Crown copyright, 2012/a).

\section{Az iskolai teljesítményértékelés}

Ezt a fontos elemet itt csak röviden érintem, mert erről a kérdésröl 2011-ben egy hosszabb írást publikáltam, melyben részletesen ismertettem a rendszer müködését (Király, 2011). A felügyeletről szóló magyar szakirodalom erről a „pillérről” - valamilyen rejtélyes okból - egész egyszerủen nem vesz tudomást, pedig ez az intézmény a magyar értelemben vett szaktárgyi (szak)felügyelet angol megfelelöjének tekinthető. Megjegyzendő, hogy az egyes szaktanárok munkáját felügyelő vagy azt segítő külső szakfelügyeleti rendszer Angliában nem létezik.

\section{Az iskolai teljesitményértékelés}

Az iskolai teljesítményértékelést (amelyet 2007 és 2012 között teljesítménymenedzsmentnek neveztek) az 1991-es, azóta többször módosított Értékelési rendelet (Education [School Teacher Appraisal] Regulations, 1991) vezette be, amelynek legutóbbi változata 2012 szeptemberében lépett életbe. (Crown copyright, 2012/b).

A teljesítményértékelés a 2012-ben egységesített és lényegesen leegyszerüsített Tanári sztenderdek - amolyan minimumkövetelmények - (Crown copyright, 2012/c) alapján folyamatosan, éves ciklusokban történik, az iskolavezetés és/vagy a munkaközösség-vezető és természetesen az érintett tanár közremüködésével. Az értékelés tervezési szakaszában a tanár és az értékelő megegyeznek abban, hogy mi 
kerüljön a tanár munkájának fókuszába az adott évben. A kiindulópont elsősorban a sztenderdekben megfogalmazott kompetenciák listája, de lehet akár a tanár által javasolt bármilyen egyéb dolog is, ami a tanulók eredményesebb tanulását segítheti. A megfigyelés időszakában az értékelö folyamatosan figyelemmel kíséri a tanár munkáját, beszélgetéseket folytat vele, és az év során - amennyiben szükségesnek látja -, meg is látogat egy vagy több tanórát. Az óralátogatás során az iskola által központilag készített megfigyelési lapot használ az értékelésre, amelyben azonban kizárólag csak az elöre megbeszélt szempontok alapján értékeli a tanár munkáját. Az értékelési ciklus végén egy értékelő beszélgetést (ún. interjút) tartanak, amelynek során az értékelö és az értékelt is elmondja véleményét a tanár teljesítményével kapcsolatban, és megállapodnak abban, hogy mi volt sikeres az elmúlt időszakban, illetve, hogy mi szorul javításra az elkövetkezendökben. Ezeket a megállapításokat a megbeszélés után írásba foglalják, majd a dokumentumot mindkét fél aláírja. Az értékelés során gyüjtött adatok, információk bizalmasak, csak az érintett és az értékelők férhetnek hozzá, és munkahely-változtatás esetén sem adhatók ki, azonban felhasználhatóvá válnak a fizetési küszöbök, valamint a pályaszakaszok átlépésével kapcsolatos iskolavezetői döntésekben, tehát az értékelés alapvetően kettős, egyszerre fejlesztő és minösitö jellegü. Az (anonim) iskolai összesített értékelési adatokba az Ofsted felügyelői is betekinthetnek a felügyeleti látogatások során (Király, 2011).

\section{A gyakornoki idöszak}

A szakfelügyelet speciális formájának tekinthető a gyakornoki időszak (többnyire a kezdő tanár első iskolában töltött tanéve) alatti, helyi, iskolán belüli folyamatos „szakfelügyelet”. Ennek során a kezdő tanárnak egy kijelölt, tapasztalt, szakos mentor-kolléga támogatásával és felügyelete mellett bizonyítania kell, hogy - a kezdő tanártól elvárható szinten (Class teacher) - képes teljesíteni a Tanári sztenderdekben definiált alapkövetelményeket. (Lásd részletesebben: Király, 2011 és 2013.)

\section{A teljesitményértékelés és a pályaszintek összefüggése}

A 2006-os teljesítménymenedzsmentről szóló Oktatási rendelet (The Education [School Teacher Performance Management] [England] Regulations 2006) (HMSO, 2006) 2007-es hatályba lépése óta közvetlen kapcsolat van az értékelés és a bérezés között. Az értékelés során keletkezett információk a javadalmazással kapcsolatos (a naptári év végén az elbíráló szervekhez továbbítandó) értékelői ajánlások alapját képezik, így a belső, iskolai, de a Tanári sztenderdek mint objektív referenciapontok alapján müködő teljesítményértékelés szerepe nagyon felértékelődött a fizetési küszöbök, valamint a pályaszakaszok átlépéséról történő döntésekben. Ez annak ellenére igaz, hogy elvileg az értékelés és az előmenetellel kapcsolatos döntéshozatal továbbra is külön eljárásban történik, sőt, a „Kiváló tanár” és a „,Kiemelkedö Képességü Tanár” (,,Vezetötanár”) státuszok elbírálása külső és nem házon belüli minősítési eljáráson nyugszik. 
Mint láttuk, az első, pályakezdő évben az értékelés célja az, hogy segítse a pedagógust a „Tanár” (Class teacher) szint elérésében, illetve, hogy az értékelés eredményei meggyőzően igazolják ennek a kötelező alapszintnek az elérését. A tanár munkáját ennek során minden harmadév ${ }^{1}$ végén értékelik, majd a tanév végén felterjesztik a „Tanár” fokozatra. A kezdő tanár ezzel a hatfokozatú ún. Fö Fizetési Skála (Main Scale) kezdőpontjára, az M1-es fizetési fokozatba kerül, majd a továbbiakban ezen a hatfokozatú skálán halad tovább a pályán eltöltött idő és a mutatott teljesítmény alapján, úgy, hogy - az értékelés során igazolt - jó teljesítmény esetén, az igazgató döntése függvényében, évente egy-egy fizetési fokozattal léphet elöre. A hat fokozat teljesítésének nincs időbeli korlátja, de a második, a „küszöbszint utáni”, ún. Felső Fizetési Skálára (U1 fokozatba) kerülés kérvényezése előtt két egymást követő évben a „,Minösitett tanártól” (Post Threshold Teacher) elvárható szinten teljesített sztenderdeknek való megfelelést igazoló értékelésen kell átesnie. A kérvényt az iskola felügyeleti szervéhez (Governing Body) kell benyújtani az igazgató ajánlásával. Az ehhez a pályaszinthez rendelt háromszintü progresszív fizetési skálán való előrehaladás itt is az értékelés eredményei és az igazgató javaslata alapján történik, úgy, hogy az újabb fizetési szintre lépés kétévenként lehetséges a felügyeleti szerv döntése alapján.

A ,Kiváló Tanár” (Excellent Teacher) és a „,Kiemelkedö Képességü Tanár” / (,,Vezetötanár") (Advanced Skills Teacher) szintek megítélése - az érintett tanár kezdeményezésére - már nem az előbbi pályaszakaszok esetében ismertetett módon történik, hanem a kérvényt egy országos minősítő bizottsághoz (ez jelenleg a National Assessment Agency nevü szervezet) kell benyújtani. Ez az intézmény elöször ellenőrzi a formai követelmények meglétét, például - egyebek között - az iskolának és a felügyeleti szervnek igazolnia kell, hogy képes finanszírozni a fokozattal járó javadalmazást, valamint áttekintik a belső értékelések eredményeit is. Amennyiben itt mindent rendben találnak, akkor egy külső minősítőt küldenek ki, aki egy teljes napig tartó vizsgálat során - a jelölttel történő beszélgetés, a benyújtott portfólió alapos elemzése és az igazgatóval való megbeszélés alapján - bizonyosodik meg arról, hogy a jelölt megfelel-e a pályaszintek speciális elvárásainak, amelyek leginkább a pályaszintekhez tartozó és kötelezően ellátandó funkciókra való alkalmasság vizsgálatát jelentik. Ezek a funkciók a „Kiváló Tanár” esetében az iskolai mentorálásban és az értékelésben való részvétel és egyéb, az egész iskola müködésére kiható, középvezetői szintü tevékenységek, míg a „Kiemelkedö Képességü Tanár" esetében - a fentieken kívül - elvárás az is, hogy a jelölt szakértelemét a saját iskolai keretein túl is hasznosítsa (Király, 2011). Jelenleg a legmagasabb szint szükségessége felülvizsgálat alatt áll, és lehet, hogy hamarosan egy speciális, „szakértő tanár" státusszal fogják helyettesíteni.

\footnotetext{
${ }^{1}$ Angliában a tanév három trimeszterből (harmadévből) áll.
} 


\section{A tanfelügyelet: a teljes $O f$ sted felügyeleti látogatás}

Az Ofsted ún. „teljes, 5. fejezet típusú” (full Section 5 inspection - utalás a 2005-ös Oktatási Törvény ötödik fejezetére, amely az ilyen vizsgálatokat elrendeli), azaz „normál” felügyeleti látogatása nem az egyes pedagógusokra, hanem az intézmény egészének teljesitményére koncentrál. Elsősorban nem a tantárgyi tanítást elemző, hanem komplex intézményértékelési aktusról van szó, amelynek deklarált célja $a z$ egyes iskolák minősitése és fejlesztése, azaz - amennyiben szükséges - jobb munkára, valamint - kiváló eredmény esetén - a színvonal tartására való ösztönzés. Független külső vizsgálatról van szó, amely értékeli az iskola eredményességét és diagnosztizálja azokat a problematikus területeket, amelyek esetében fejlesztésre van szükség. A látogatás során a felügyelők különböző bizonyítékokat keresnek, amelyeket aztán összevetnek az országos keretrendszerrel (Crown copyright, 2013/b), majd ez alapján minősítik az iskolát.

\section{Az Ofsted küldetése és a vizsgálatok fö elvei}

Az Ofsted (2013) három alapvető funkció ellátásában fogalmazza meg küldetését:

- A szülők szakmailag megalapozott és független információval való ellátása az iskolák teljesítményével kapcsolatban, annak érdekében, hogy ki tudják választani gyermekeik számára az igényeiknek leginkább megfelelö iskolát. Ezt a felügyeleti látogatásokról szóló, a laikusok által is könnyen értelmezhető jelentések nyilvános hozzáférhetősége biztosítja.

- Az oktatási miniszter és a Parlament információkkal való ellátása az iskolákban folyó munka minőségével kapcsolatban. Ennek célja az, hogy láthatóvá váljon, hogy az iskolák teljesítik-e a tőlük elvárható minimumkövetelményeket és azt, hogy a közpénzeket megfelelően használják-e fel. Az Ofsted vizsgálatai alapján minden évben benyújtja a Parlamentnek az adatokat összesítő és értelmező éves jelentését.

- Elösegíteni az egyes iskolák és az egész oktatási rendszer fejlődését. Ez az iskoláknak már a vizsgálat során szóban közölt információkon, majd a vizsgálat lezárultával a részletes, írásbeli felügyeleti jelentésen, azon belül is az értékelésen és a javítandó aspektusok megnevezésén, illetve a változások későbbi nyomon követésén keresztül valósul meg.

Müködésének alapelveit az Ofsted a következőképpen fogalmazza meg:

- A tanfelügyelet támogatja és elösegiti az oktatás fejlesztését azáltal, hogy...

- világos sztenderdekben fogalmazza meg az elfogadható minőség kritériumait - csak a ,jó" iskola lehet elég jó;

- a legnagyobb hatékonyság elérésének megfelelően szabja meg a vizsgálat irányát és jellegét/típusát; 
- egyértelműen azonosítja az iskola erősségeit és gyengéit;

- pontosan meghatározza az ajánlásokban megfogalmazott célok teljesítéséhez szükséges tennivalókat;

- megindokolja a vizsgált iskoláknak a megítélt minősítéseket, és meg is vitatja velük azokat;

- folyamatosan ellenőrzi a leggyengébb iskolákat, feladatokat szab meg és egyben támogatást is nyújt az iskolavezetés és a tantestület számára a munka javítására.

- Arányos abban az értelemben, hogy...

- a látogatások számát az előző vizsgálat minősítésének, illetve az ún. „kockázati elemzés” (Lásd 2.5.) függvényében szabja meg;

- az erőforrásokat oda csoportosítja át, ahol a legnagyobb szükség van a fejlődésre, vagy ahol a vizsgálat a legnagyobb hatással lehet a fejlödésre.

- Különös figyelmet szentel a tanulók és a szülők igényeire, azáltal, hogy...

- figyelembe veszi véleményüket a látogatás tervezése és lebonyolítása során;

- figyelembe veszi véleményüket a felügyelői minősítésekkel kapcsolatos döntések során;

- fokozottan ügyel a gyermekek, fiatalok és felnőttek biztonságára, azzal, hogy értékeli az iskola ezzel kapcsolatos tevékenységét;

- felméri, hogy mennyire sikerült az iskolának olyan környezetet biztosítania, amely megfelel minden tanuló igényeinek, korra, nemre, bármilyen fogyatékosságra, fajra, vallásra, szexuális orientációra való tekintet nélkül.

- Figyelmet szentel az iskola igényeire, azáltal, hogy...

- magas színvonalú és időben történő tájékoztatást ad az iskolának;

- a lehetőségekhez képest legmesszebbmenőkig felhasználja a hozzáférhető létező adatokat, dokumentumokat és rendszereket, hogy minél kevesebb terhet rójon rájuk a felügyeleti látogatással;

- figyelembe veszi az iskolai önértékelést, amelynek tartalmát és formáját az új szabályozás szerint maga az iskola szabja meg (eddig egy Ofsted formanyomtatványt kellett használni).

- Transzparens és következetes, abban az értelemben, hogy...

- szilárd bizonyítékokon alapuló, transzparens és következetes ítéleteket alkot;

- tisztességesen jár el mind maga a vizsgálat, mind pedig a jelentések összeállításának tekintetében.

- Elszámoltatható abban az értelemben, hogy...

- fenntartás és elfogultság nélkül fogalmazza meg az inspekció eredményeit; 
- egyértelmű, pontos, megbízható és független információkkal látja el a most az iskolába járó tanulók és az iskola leendő diákjainak szüleit az iskola által nyújtott oktatás színvonalával kapcsolatban;

- megkérdezi és figyelembe is veszi az iskola tanulóinak, a tanulók szüleinek és mindenki másnak a véleményét, aki valamilyen értelemben érdekelt az iskola müködésének minőségében;

- biztosítja, hogy a tanfelügyeletre költött költségvetési forrás ne legyen kidobott pénz;

- hatékonyan és gazdaságosan osztja el és használja fel a forrásokat;

- folyamatosan értékeli az elért eredményeket és a felügyeleti eljárásokat, és szükség esetén a nagyobb hatékonyság és célszerüség céljából módosítja azokat (Ofsted, 2010).

\section{Az Ofsted mint intézmény}

A központi tanfelügyelet az 1992-es (azóta többször módosított) Oktatási Törvény bevezetése óta az Ofsted (Oktatási Sztenderdek Hivatala, Office for Standards in Education) feladata. Ez az intézmény - szemben elődjével, az Öfelsége Tanfelügyeletével (Her Majesty's Inspectorate - HMI), amely az Oktatási Minisztérium részeként müködött -, egy, a minisztérium mellett müködő, független, országos szervezésủ felügyeleti-értékelési hatóság. 2005 óta a szigorú értelemben vett iskolai tanfelügyeleten kívül feladatai közé tartozik a közszolgálati szféra számos egyéb területének szabályozása és felügyelete is, mint például a gyermek-szociális ellátás különböző szolgáltatásai, a bölcsőde, az óvoda, a napközi, a gyermekvédelem, a felnőttképzés, a tanárképzés és továbbképzés bizonyos aspektusainak felügyelete is.

A feladatokhoz illeszkedően hatalmas intézményről van szó, több ezer fö- és részfoglalkozású alkalmazottal. Az Ofstedet a föigazgató (Öfelsége Fö Tanfelügyelöje, Her Majesty's Chief Inspector - HMCI) vezeti, akinek munkáját egy kilenctagú bizottság (The Ofsted Board) segíti, akiknek tagjai stratégiai tanácsokat adnak, és részt vesznek a döntéshozatalban. A napi müködést hét, egy-egy részterületért felelős igazgató irányítja. (E részterületek például: iskolák felügyelete, pénzügyek, stratégiai kérdések, tanulás és készségfejlesztés, kisgyermekkor stb.)

Az Ofsted, amelynek központja Londonban van, (2009-es adatok szerint) 443 felügyelöt (Her Majesty's Inspectors - HMIs) alkalmaz fóállásban, akiknek nagyjából a fele vesz részt felügyeleti látogatásokban (a többiek vezetők, statisztikusok, egyéb szakértők, vagy az adminisztratív munkában vesznek részt). Magát a vizsgálatot - amelyet középiskolák esetében legtöbbször egy főállású felügyelő vezet többnyire a mintegy 2000 „részfoglalkozású” (Additional Inspectors - AI) bonyolítja le, akiknek munkáltatója valójában egy-egy külső cég. Három ilyen van; egyegy Bristolban, Nottinghamben és Manchesterben, ezek az ún. Regionális Felügye- 
leti Szolgálatot Ellátók (Regional Inspection Service Providers - RISPs) (Gilbert, 2009). A felügyelői állásra pályázni kell; követelmény a tanítási és vezetői tapasztalat. A felvett felügyelők alapos kiképzésben részesülnek, és rendszeresen kell továbbképzésekre is járniuk. Az Ofsted költségvetése 2009-2010-ben 217 millió angol font volt (Ofsted, 2010).

\section{Az eredmények nyilvánossága}

A teljes (normál) Ofsted vizsgálatok során született értékelési eredmények teljesen nyilvánosak, ráadásul nem csak az iskola általános minősítése, hanem az iskoláról készült teljes felügyeleti jelentés is. Az anyag - kedvező minősítés esetén a látogatást követő 15 , elmarasztaló minősítés esetén 28 munkanapon belül felkerül az Ofsted honlapjára. Különösen vigyáznak arra, hogy a jelentések nyelvezete abszolút közérthető legyen (lásd például a nagyon egyszerü minősítő skálát), hiszen a jelentések egyik legfontosabb célközönsége a szülöi közösség és a szélesebb értelemben vett laikus nagyközönség.

\section{A vizsgálat során használt értékelési minösitések}

2012 szeptemberében az Ofsted újradefiniálta az vizsgálatai keretrendszerének legfontosabb vonásait. Az új - teljesen nyilvános, bárki számára hozzáférhető - irányelvek szerint a továbbiakban a látogatások során a felügyelök különös figyelmet fognak szentelni az iskolai munka azon aspektusaira, amelyek a legnagyobb hatással lehetnek a teljesítmény javítására. Ennek megfelelöen négy olyan területet emeltek ki, amelyekről a felügyelőknek kötelező ítéletet alkotniuk, így a vizsgálat során az iskola hatékonyságának megítélése elsősorban ennek a négy kulcsterületnek az értékelése alapján történik. Ezek a területek a következők:

- az iskola tanulóinak tanulmányi teljesítménye;

- a tanítás minősége az iskolában;

- a tanulók magaviselete és biztonsága;

- az iskola vezetésének és menedzsmentjének színvonala.

A fenti kulcsterületeken kívül a felügyelőknek fel kell mérniük az tanulók szellemi, morális, szociális és kulturális fejlődését is, különös figyelmet kell szentelniük a legkülönbözőbb hátterü tanulók egyedi igényeinek, mindenekelőtt pedig a fogyatékkal élö, illetve speciális nevelési-oktatási igényü tanulók szükségleteinek megfelelő kielégítésére.

Az egyes kulcsterületek értékelése egy rendkívül egyszerü, holisztikus, négyfokozatú skála (1-től 4-ig) alapján történik, amelyben a következő „osztályzatok” adhatók: 1-es, azaz „,kiváló”; 2-es, azaz ,jó ”; 3-as, azaz „,fejlesztést igénylö”; 4-es, azaz ",nem megfelelö". Az utóbbin belül két alkategória is van: lehet az iskola „,súlyos hiányosságokkal rendelkezö” vagy „rendkívüli intézkedéseket igénylö”. A 3-as és 
4-es minősítésű iskolákat gyakran nevezik az „,aggodalomra okot adó” kategóriába tartozó intézményeknek is.

Az iskola végső, összefoglaló minősitésének megállapítása a következő szempontok figyelembevételével történik:

- Az elfogadható teljesítményt a ,jó" minősítés elérése jelenti. A felügyelőknek el kell dönteniük, hogy eléri-e a tanítás minősége a 2-es (,jó”) minösítést, illetve kaphat-e 1-est, azaz „kiváló” minősítést. Nem minősíthető azonban egy iskola „kiválónak”, ha a 'tanítás minősége' kulcsterület esetében nem sikerül „kiváló” minősítést elérnie.

- Az iskola végső minősítése „fejlesztést igénylő” lesz, ha a négy terület közül egy vagy több kulcsterületen nem sikerült elérni legalább a 2-es, „jó" minősítést, vagy ha problémák mutathatók ki a tanulók szellemi, morális, szociális és kulturális fejlődésével kapcsolatban.

- Amennyiben az iskola „nem megfelelő” minősítést kap, azaz a hivatalos megfogalmazás szerint „,aggodalomra ad okot”, el kell dönteni, hogy a „súlyos hiányosságokkal rendelkező iskola” vagy a „rendkívüli intézkedéseket igénylő iskola" kategóriába kerüljön-e.

- A „súlyos hiányosságokkal rendelkező iskola” kategóriába sorolandók azok az intézmények, amelyek egy vagy több kulcsterületen 4-es, „nem megfelelő" minősítést kaptak és/vagy problémák mutathatók ki a tanulók szellemi, morális, szociális és kulturális fejlődésével kapcsolatban, amennyiben az iskolavezetés és iskolamenedzsmentet képesnek ítélik arra, hogy biztosítsa a jövőben a javulást (azaz legalább 3-as osztályzatot kap).

- A „rendkívüli intézkedéseket igénylő iskola” kategóriába kell sorolni azokat az intézményeket, amelyek nem képesek megfelelő minőségü oktatástnevelést biztosítani tanulóik számára, valamint az igazgatóság és az iskolavezetés nem bizonyultak alkalmasnak arra, hogy a jövőben önállóan biztosítani tudják a szükséges fejlődést.

Az Ofsted rendszeresen felülvizsgálja vizsgálati kritériumait, és ezeknek a felülvizsgálatoknak az eredménye szinte mindig valamilyen szigorítás. Jó példa erre a 2009. évi felülvizsgálat, amelynek eredményeképpen 2010-re 19 százalékról 9 százalékra csökkent a „kiváló” minősítést kapott iskolák, és 4 százalékról 10 százalékra nőtt a „nem megfelelőnek” ítéltek aránya (BBC News, 2010).

\section{Az ellenörzések gyakorisága}

A normál, „teljes, 5. fejezet típusú” felügyeleti látogatások gyakoriságát a megújított Ofsted keretrendszer (Crown copyright, 2013/b) alapesetben az utolsó vizsgálattól eltelt öt évben határozza meg, de a tényleges gyakoriságot attól teszi függővé, hogy milyen volt az egyes iskolák előző minősítése. Az alapeset az utolsó látogatás során ,jó” minősítést kapott iskolákra vonatkozik, amelyek (ha más probléma nincs) 
öt év múlva számíthatnak vizsgálatra, de ennek tényleges időpontja a (az utolsó teljes vizsgálat utáni harmadik év végétől évente ismétlődő) „kockázati elemzések” (lásd részletesebben lejjebb) eredményétől függ.

Mentességet kapnak azok az iskolák, amelyek a legutóbbi vizsgálat során „kiváló" minősítést értek el. Ez a mentesség azonban felfüggeszthető, ha valamilyen panasz érkezik az iskolára az Ofstedhez, vagy ha a látogatás utáni harmadik év végén (december, esetleg január) először kötelezően végrehajtott ún. „kockázati elemzés” (risk assessment) valamilyen aggodalomra okot adó információt mutat ki. Ennek során megvizsgálják az iskola tanulóinak a felmérésekben nyújtott teljesítményét, a hiányzások számát, az on-line szülői értékelések és az Ofsted tematikus vizsgálatainak eredményeit. Az első kockázati elemzéstől kezdve ezt a vizsgálatot minden év végén megismétlik, eredményét megküldik az iskoláknak, valamint fel is teszik az Ofsted honlapjára (Crown copyright, 2011).

Azok az iskolák azonban, amelyek az utolsó vizsgálaton a ,fejlesztést igényel" kategóriába soroltak, két éven belül nagy valószínüséggel újabb vizsgálatot fognak kapni, és visszajelzést arról, hogy történt-e javulás. Amennyiben három egymás utáni (kétévenként történő) felügyeleti látogatás során is csak ilyen minősítést kap az iskola, akkor „nem megfelelőnek” minősítik át, és ennek megfelelően a „rendkívüli intézkedéseket igénylő iskola” kategóriába kerül. Azok a „,nem megfelelo" minősítést kapott iskolák, amelyekben viszont az iskolavezetés és menedzsment minősítése nem ilyen, azok 18 hónapon belül számíthatnak újabb vizsgálatra, és azok, ahol az iskolavezetés és menedzsment minősítése is ilyen, (azaz a „rendkívüli intézkedéseket igénylő iskola" kategóriába kerültek) speciális vizsgálatot kapnak három hónapon belül, és ez másfél év alatt ötször is megismétlödhet, ha addig sem sikerül magasabb kategóriába kerülni (Crown copyright, 2013/b).

Ofsted ellenörzést kérni is lehet; így kérheti a Helyi Oktatási Hivatal (LEA), a tanárok, a szülők, a tantárgyi vagy a tematikus vizsgálatban részt vevő tanfelügyelők, sőt akár maga az iskola is. A rendkívüli felügyeleti látogatás szükségességével kapcsolatos döntést az Ofsted föigazgatója hozza meg.

\section{Az vizsgálat fókuszai}

Az Ofsted Tanfelügyeleti Kézikönyve (School inspection handbook) részletes eligazítást nyújt mind a tanfelügyelők, mind pedig az iskolák számára, hogy milyen kulcsterületeket kell vizsgálni a látogatás során. (Crown copyright, 2013/a) Az iskolák összesített hatékonyságához, valamint a négy terület megítéléséhez minősítésenként részletezett indikátorlista áll rendelkezésre, azaz összesen 20 olyan lista létezik, amelyet a felügyelők a pontos minősítés azonosításához fel tudnak használni, bár a Kézikönyv figyelmezteti a felügyelöket, hogy ne használják ezeket tételes ellenőrzési listaként. Az egyes területen belüli listák azonos dolgokra fókuszálnak, de a megfogalmazások a minősítés szerint változnak. Például, a „kiváló” (1-es) minő- 
sítésnél az szerepel, hogy ,az országos átlaghoz képest magas azon tanulók részaránya...”, a ,jó” (2-es) minősítésnél a „többségben vannak azok a tanulók” kifejezés szerepel, míg a leggyengébb, „nem megfelelő” (4-es) minősítésnél az, hogy „a tanulók általában vagy egyes csoportjaik rendszeresen...”. A harmadik, „fejlesztést igénylő" minősítés esetében nincs részletes leírás, ezt a 2-es és a 4-es listákból kell levezetni. Nagyjából ilyen logika alapján múködik az összes skála. (Crown copyright, 2013/a)

\section{Az iskola tanulóinak teljesitménye}

Ez a terület mindenekelött a tanulók tanulmányi eredményeit öleli fel, amelyeket mind a tanulók által mutatott fejlődés, mind pedig a konkrétan elért eredmények alapján vizsgálnak. Ennek megfelelően figyelembe veszik a tanulók előző tantervi szakaszok végén a Nemzeti Tanterven alapuló sztenderdizált teszteken elért eredményeit. Ezek az ún. SAT - Standardised Assessment Test tesztek, amelyeket angolból, matematikából, természettudományból írnak meg a tanulók Az elsőnél (Key Stage 1) a 7 éves, a másodiknál (Key Stage 2) a 11 éves korban, a harmadiknál (Key Stage 3) a 14 éves korban megszerzett tudás szintjét mérik. (Az első kettő országos teszt, a harmadik azonban a normál iskolai év végi osztályzatok alapján születik). Különösen nagy figyelmet szentelnek a legrosszabb és a legjobb eredményeket produkáló tanulók előrehaladásának nyomon követésére. (Crown copyright, 2013/a)

Az ezek megítéléséhez szükséges adatokat (a mérési adatokon túlmenően) a legváltozatosabb forrásokból, így - egyebek között - az óralátogatások tapasztalataiból, a tanulók munkájának és tanulmányi eredményeinek vizsgálatából, a szülőkkel, diákokkal, a tanárokkal folytatott beszélgetésekböl, valamint - föleg általános iskolák esetében - a tanulók helyszíni (hangos) olvastatásával (!) gyüjtik be.

\section{A tanitás minősége az iskolában}

A felügyelők az osztálytermi és osztálytermen kívüli tanulási tevékenységek tervezését és lebonyolítását vizsgálják a különböző tantárgyakban, valamint az osztályzást, értékelést és a tanulók számára nyújtott egyéb tanári visszajelzéseket. Figyelmet fordítanak arra, hogy a tanárok milyen stratégiákat alkalmaznak a diákok segítésére és arra, hogy mit tesznek a tanulók szellemi, morális, szociális és kulturális fejlődésének érdekében.

A végső minősítésnél nem egyszerủen az óralátogatások minősítéseinek átlaga alapján hoznak döntést, hanem figyelembe kell venniük a tanulók fejlődését dokumentáló adatokat is. A tanárok munkáját a Tanári sztenderdek alapján kell megítélni, és nem lehet elvárás az, hogy a tanár egy bizonyos konkrét módszertani elv alapján vagy valamilyen speciális technika alkalmazásával tanítson. Az adatgyüjtés elsődleges forrása itt az óralátogatás, de a felügyelők tudatában vannak annak, hogy egy rövid látogatás során a tanulás-tanítás nagyon sok fontos eleme egyszerü- 
en nem figyelhető meg. Ezért a végső minősítésnél figyelembe kell venniük az iskolai teljesítményvizsgálatok eredményeit, valamint a tanulók, a szülők és tanárok véleményét is. (Crown copyright, 2013/a)

\section{A tanulók magaviselete és biztonsága}

Ez a szempont fontos szerepet játszik az iskolának a tanulók szellemi, morális, szociális és kulturális fejlődésének érdekében végzett munkájával kapcsolatos minősítés megítélésében. Ehhez a lehető legkülönbözőbb forrásokból (a helyszíni információkon kívül az esetleges korábbi panaszokra, bejelentésekre stb. is figyelve) igyekeznek bizonyítékokat gyüjteni a felügyeleti látogatás során. Vizsgálják a tanuló tanórai és órán kívüli magaviseletét, a tanuláshoz való hozzáállását, azt, hogy milyen eszközökkel és hatásfokkal tudják a tanárok a fegyelmet fenntartani, valamint ellenőrzik a hiányzások és késések mértékét is. (Crown copyright, 2013/a)

\section{Az iskola vezetésének és menedzsmentjének szinvonala}

E szempont kapcsán az iskolavezetésnek az iskolára gyakorolt hatását vizsgálják, azt értékelik, hogy mennyire hatékony az iskola menedzselése. Különös figyelmet szentelnek annak megállapítására, hogy az iskolavezetés és az az iskolaszék tevékenysége mennyire segíti a tanulást a különböző (tanári és tanulói) szinteken. Vizsgálják az elvárások színvonalát, a tanterv gazdagságát és kiegyensúlyozottságát, hogy biztosítva vannak-e a megfelelő továbbképzési lehetőségeket a tanárok számára, hogy kellően bevonják-e a szülőket a tanulók fejlődésének elősegitésébe, valamint azt, hogy milyen intézkedéseket vannak érvényben a tanulók biztonságának biztosítására az iskolában. (Crown copyright, 2013/a)

\section{Az felügyeleti látogatás menete}

\section{A felügyelöi team}

Magát a vizsgálatot az Ofsted által megbízott „külsős” cégek, az ún. Regionális Felügyeleti Szolgálat Ellátók (RISPS) szervezik és bonyolítják le, jórészt saját alkalmazásban lévő „másodállású” felügyelöik (Additional Inspectors, AIs) közremüködésével, de - föleg középiskolák esetében - a team vezetóje egy fóállású felügyelő (Öfelsége Tanfelügyelöje: Her Majesty's Inspector, HMI). A felügyelői team tagjainak száma az iskola méretétől és típusától, valamint a vizsgálat komplexitásától függ. A csapat minimum három, maximum akár öt főből áll, akiket még kiegészíthetnek speciális (pl. a szociális ellátást vizsgáló) szakértőkkel is.

A felügyelők alaposan felkészülve érkeznek az iskolába: átnézik az előző vizsgálatok anyagait, az országos felmérésekben az iskola által elért eredményeket (ezek a nyilvános eredmények bárki számára hozzáférhetők a RAISEonline adatbá- 
zisból), bármilyen az Ofsted által végzett, időközi - tantárgyi vagy tematikus - vizsgálat jelentéseit, áttekintenek minden, az elmúlt időszakban az iskolával kapcsolatban beérkezett esetleges panaszt, valamint megnézik az iskola honlapját is.

Ezek alapján a felügyeleti team vezetője kijelöli a vizsgálat legfontosabb fókuszait, majd összeállítja a látogatás programját, valamint kiosztja az egyes felügyelőknek a feladatokat, úgy, hogy minden tagnak részt kell vennie mind négy terület értékelésében, hiszen a minősítéseknek az összes tag egyetértésével kell megszületniük.

\section{Az iskola teendöi a látogatás elött}

A felügyelők a vizsgálatról, amely normál esetben két teljes munkanapon keresztül tart, az iskolát a látogatás kezdetét megelőző nap délutánján értesítik a tanfelügyelök érkezéséröl, bár elvileg bejelentés nélkül is megjelenhetnek. A bejelentkezés telefonon, az igazgatónál (vagy távollétében a jelenlévő legmagasabb rangú iskolavezetőnél) történik, elképesztően részletesen elöírt protokoll szerint (a Kézikönyv még a pontos, szó szerinti szöveget is megadja, amellyel közölni kell a látogatás tényét!) A vizsgálat gyakorlatilag semmilyen indokkal nem halasztható el.

Az iskolának látszólag nagyon kevés konkrét feladata van a látogatás előkészítésével kapcsolatban, de az alábbi felsorolásból jól látszik, hogy a telefon utáni délutánra és estére bőven jut teendő. Talán a legfontosabb ezek közül az, hogy azonnal értesíteniük kell - az Ofsted által e-mailben megküldött szabványosított értesítő használatával, de kötelezően papíralapon is, - a szülőket a látogatás tényéről és arról, hogy a következö két nap során mikor és hogyan vehetik fel a személyes kapcsolatot a felügyelőkkel. (Ezt még a felügyelőkkel folytatott első telefonbeszélgetés során tisztázni szokták, és általában egy-egy délutáni „fogadóóra” szokott lenni.) Hasonlóan, az iskola köteles értesíteni az iskola dolgozóit, valamint összes felettes és felügyeleti szervét is a látogatásról, valamint közölni kell az érintettekkel a vizsgálat alatti értekezletek időpontjait. Ezen kívül csak az - állandóan naprakészen tartott - önértékelési dokumentumokat és az előzetesen, a telefonos bejelentkezéskor kért egyéb dokumentumokat (az iskolai pedagógiai programot, órarendet, nyilvántartásokat az iskola dolgozóival és a tanulókkal kapcsolatban, jelenléti íveket, hiányzási naplókat, fegyelmi határozatokat stb.) kell előkészíteniük.

\section{Az adatgyüjtés folyamata}

A látogatás egy rövid eligazítással kezdődik, ahol a vezető felügyelő és az igazgató kölcsönösen bemutatják stábjuk tagjait egymásnak, meghallgatnak egy rövid helyzetjelentést (hiányzók, bármilyen egyéb fontos információ), majd megbeszélik a felügyelet menetét. A látogatás során a felügyelök idejük legnagyobb részét tanórák és tanórán kívüli foglalkozások látogatásával töltik, de a döntések meghozatalában 
figyelembe veszik a szünetekben és egyéb iskolai tevékenységek (például ebéd) során tapasztaltakat is.

Az óralátogatások pár perces villámlátogatásoktól 20-25 perces óraszeletek látogatásán, teljes órák meglátogatásán, és egyes csoportok egész napos kísérésén át a legváltozatosabb formában történhetnek. Az óralátogatásnál felajánlják az iskolavezetőség tagjainak, hogy elkísérhetik őket a látogatásra. A látogatás után (a néhány perces villámlátogatások kivételével) mindig adnak visszajelzést a meglátogatott tanárnak (ha iskolavezető is jelen van, akkor ő vezeti a beszélgetést), amelynek hossza és alapossága a látogatás hosszától függ. Nem feltétlenül látogatnak meg minden tanárt, de igyekeznek minél több órát megnézni. Az órára bejelentés nélkül érkeznek, és nem kérnek semmiféle óratervet.

A látogatás során folyamatosan - személyesen vagy kérdőíves formában - kikérik (az óralátogatás során vagy a szünetekben, sőt akár formális találkozó szervezésével is; ilyenkor az iskolavezetés tagjai nem lehetnek jelen) az iskola tanulóinak, valamint a tantestület tagjainak és az iskolai egyéb dolgozóinak véleményét is. Ezen kívül ellenőrzik azt is, hogy milyen megjegyzések érkeztek az iskolával kapcsolatban az Ofsted Szülöi vélemények (Parent View) elnevezésü, on-line kérdőíves fórumára, amelynek linkjét az iskola köteles feltenni az iskolai honlapra. (Ide csak regisztrált felhasználók léphetnek be, és - természetesen - csak a „saját” iskolájukkal kapcsolatban fejthetik ki véleményüket a látogatás ideje alatt). A vélemények lehetnek anonim megjegyzések is; ezt a felügyelőknek szigorúan tiszteletben kell tartaniuk.

$\mathrm{Az}$ adatok gyüjtése technikailag az Ofsted szabványosított adatlapjainak (evidence forms) kitöltésével történik. A kódokkal és szöveges részekkel kitöltött adatlapokat begyüjtik, és ez a gyüjtemény a végső minősítéshez szükséges adatbázis részévé válik (Crown copyright, 2013/c). Az egyes területekre vonatkozó minősítéseket a területet vizsgáló felügyelök kollektív döntése alapján hozzák meg az összes rendelkezésre álló adatforrás figyelembe bevételével, szigorúan az adatlapok tartalmára és az egyéb forrásokból (RAISEonline, vizsgaeredmények, felmérések eredményei stb.) származó adatokra mint bizonyítékokra támaszkodva. Egy forrás alapján nem alkotható ítélet. A felügyelők naponta háromszor értekezletet tartanak, ahol megbeszélik tapasztalataikat, de a minősítésekröl csak a második nap végén döntenek. A vizsgálat során azonosítják az iskola erősségeit és gyengeségeit, és ezeket már menet közben megtárgyalják az iskola igazgatójával vagy az adott területért felelős iskolavezetőségi taggal, aki további bizonyítékokkal járulhat hozzá az objektív végső minősítés meghozatalához. Akkor azonban, ha sejteni lehet, hogy végül „nem megfelelő” minősítés születhet, már az első nap végén figyelmeztetni kell az igazgatót, majd a team vezetöjének kötelezően telefonon be is kell jelentenie ezt a tényt az Ofsted , ügyfélszolgálatánál”, ahol konkrét eligazítást kapnak a másnapi teendőkkel kapcsolatban az ügyeletestöl. 
A második nap végi minősítésekről - amelyek ebben a stádiumban még nem számítanak véglegesnek, hiszen lehetnek utólagos panaszok, és a felügyelők az iskolából való távozás után is hozzájuthatnak újabb bizonyítékokhoz - még az iskolából való távozás elött tájékoztatják az iskolát és az iskola felettes szerveit. Abban az esetben, ha ez a minősítés „nem megfelelő”, ezt formálisan, szó szerint elöírt szavak kíséretében kell megtenniük.

A felügyelők vizsgálat alatti viselkedésével kapcsolatos elvárásokat minden részletre kiterjedő magatartási kódex írja elő, amely útmutatásokat tartalmaz a részrehajlás nélküli, objektív és kizárólag bizonyítékokkal alátámasztott ítéletalkotási kötelezettségtől a tiszteletteljes viselkedésen át, a folyamatos tájékoztatási kötelezettségen keresztül az adatok és információk bizalmasságának biztosításáig.

\section{Az vizsgálat eredményének formális közlése}

A vizsgálat eredményeit a látogatás után a vezetö tanfelügyelő egy kb. négy-öt oldalas írásbeli jelentésben foglalja össze, amelyben - a minősítés tényszerü közlésén túlmenően - először röviden vázolják az iskola kontextusát, majd röviden értékelik a négy kulcsterület mindegyikét, végül pedig kiemelik azokat a prioritási területeket, amelyek esetében feltétlenül fejlődésre van szükség. A jelentést először elküldik ez iskolának, hogy ezzel alkalmat adjanak az esetleges ténybeli tévedések kijavítására. Erre egy nap áll az iskola rendelkezésére abban az esetben, ha ,aggodalomra okot adó" minősítésnél jobb minősítést kapott, valamint öt nap akkor, ha nem. Ezután az első esetben a vizsgálat befejezését követő 10 munkanapon belül megküldik az iskolának a véglegesített jelentést, amelyet aztán 15 napon belül az Ofsted honlapján is publikálnak. A második esetben a „nem megfelelő” minősítésről szóló jelentés 28 munkanapon belül kerül fel a honlapra. Minden jelentést ellenjegyez egy föállású Felügyelö (HMI) az Ofsted igazgatójának, Öfelsége Fö Tanfelügyelöjének (HMCI) nevében. A kézhezvétel utáni öt napon belül az iskola minden szülönek is köteles megküldeni a jelentést.

\section{Minöségbiztositás, panaszok}

A felügyelet minőségbiztosításáért a team vezetője felel, és az Ofsted szúrópróbaszerüen végrehajtott belső ellenőrzés során is vizsgálja, hogy a vizsgálatok megfelelnek-e az előírt minőségi követelményeknek. Egy adott vizsgálatra vonatkozó panaszszal az iskola igazgatója először a felügyelöi team vezetőjéhez, majd - amennyiben ez nem vezetett eredményre - az Ofsted vezetéséhez fordulhat. Ezen kívül időközönként átfogó jelentéseket is közölnek az felügyeleti látogatások belső ellenőrzései és a visszajelzések alapján (Crown copyright, 2006). 


\section{A szakfelügyelet: az Ofsted tantárgyi és tematikus vizsgálatai}

A tantárgyi és tematikus vizsgálatok bevezetését először a tanfelügyeleti rendszer 2005-ös átalakítása tette szükségessé, amikor két-három napra csökkentették az Ofsted vizsgálatok időtartalmát (ez elött hatévenként egyhetes átfogó vizsgálatok voltak, amelyekről két hónappal a látogatás megkezdése előtt értesítették az iskolákat), és az új rendszerbe már nem fért bele a tantárgyak vagy egyéb, a teljes felügyeleti vizsgálat fókuszált tárgykörein kívül eső, speciális területek vizsgálata. 2012 óta a két-három nap is kettőre (és persze az értesítési idő is mindössze fél napra) csökkent, tehát még indokoltabbá vált az iskola - ahogy az angol szakirodalom nevezi - „központi idegrendszerére” koncentrált villámlátogatások speciális vizsgálatokkal való kiegészítése. A tantárgyi vizsgálatokon kívül, amelyek folyamatosan zajlanak, a legkülönbözőbb pedagógiai területeken végeznek ilyen vizsgálatokat (például a tanulók magaviseletéről) és felméréseket (például a továbbképzés helyzetéről). Az éves vizsgálati program az Ofsted és a minisztérium megállapodása alapján alakul ki, és olyan kérdésekre koncentrál, amelyeket országos jelentőségünek minősítenek. A legtöbb felmérés eredményét tanulmányban publikálják, amelyek megtalálhatók az Ofsted honlapján.

A vizsgálatok és felmérések célja, hogy további adatokkal járuljon hozzá az Ofsted éves jelentéséhez, adatokkal lássa el az Ofsted-et a ,jó gyakorlatok” terjesztéséhez, olyan részletes visszajelzéshez juttassa az iskolákat, amely segítséget nyújthat a fejlődésben, valamint hozzájárul az iskolák önértékelésének pontosításához.

Az ilyen vizsgálatok a három nagy Ofsted körzetre épülö reprezentatív minták alapján készülnek, tehát nem mindegyik iskola vesz részt minden vizsgálatban, de olyan sok van belölük, hogy a háromévenkénti teljes felügyeleti látogatás közötti időszakban gyakorlatilag minden középiskola számíthat valamilyen ilyen jellegü vizsgálatban való részvételre. (Az általános iskolákban - mivel több van belölük ennél ritkábban várható ilyen vizsgálat.)

Egy-egy vizsgálat vagy felmérés az általános iskolákban egy napig, a középiskolákban két napon keresztül tart, és a második nap végén itt is tájékoztatást kap az iskola a tapasztalatokról. A tantárgyi vizsgálatok nagyon hasonlítanak a teljes vizsgálathoz, különbség csak abban van, hogy a kritériumokat ebben az esetben az adott tantárgy viszonylatában értékelik. Az információgyüjtés alapja az óralátogatás, de ezen túlmenően itt is vizsgálják a rendelkezésre álló dokumentumokat, megnézik az iskolai önértékelés releváns adatait, beszélgetnek minden érintettel stb. Minden vizsgálatnak van egy-egy speciális fókusza is, például adott esetben kifejezetten a fiúk teljesítményére koncentrálnak egy bizonyos tantárgy esetében.

A felügyelök a tantárgyi vizsgálatok - amelyeket nyugodtan nevezhetnénk szakfelügyeletnek, de nem egészen a szó hagyományos, magyar értelmében - esetében mindig szakos végzettségüek. A meglátogatott tanárok visszajelzést kapnak, amelynek során lehetőségük van saját véleményük kifejtésére is, de a vizsgálat fó- 
kuszában itt sem az egyes tanároknak, hanem az iskola összes az adott tantárgyat tanító tanárának, azaz az iskola egészének teljesítménye áll.

Az iskolák és közvetítésükkel azok fenntartói és felügyeleti szervei írásbeli visszajelzést kapnak a vizsgálatról, de - szemben a teljes tanfelügyeleti vizsgálattal ez az anyag nem kerül fel az Ofsted honlapjára. (Természetesen az összesített eredményeket közzéteszik, de nem nevezik meg bennük az egyes intézményeket.) A vizsgálatról készült jegyzőkönyv azonban a soron következő teljes vizsgálat teamjének rendelkezésére áll, akinek fel is kell használnia annak megállapításait a minősítéseknél (Crown copyright, 2005).

\section{A tanfelügyelet szakszervezeti kritikája}

A szakszervezetek és a tanárok érdekeit képviselő lobbycsoportok, elsősorban közülük a legnagyobb, a NASUWT (National Association of Schoolmasters Union of Women Teachers), számos kifogást és félelmet fogalmazott meg az új Ofsted direktívák 2012-es bevezetése óta. Gyakorlati tapasztalat azonban - az azóta eltelt idő rövidsége miatt - egyelöre nagyon kevés van. A következőkben a NASUWT (2012) által megfogalmazott legfontosabb, problematikusnak ítélt kérdéseket foglaljuk össze:

- Aggasztja a szakszervezetet, hogy az új direktívák szerint az Ofsted vizsgálni akarja, hogy megfelelő-e a korreláció a teljesítményvizsgálatok eredményei és a tanárok fizetési besorolása között. Úgy gondolják, hogy ez a kezdeményezés gyengíti az alapvetỏen fejlesztő jellegü és sokkal alaposabb iskolai értékelés pozícióját a kérdésben, és egy olyan jellegü értékelés irányába tolja el a teljesítményértékelést, amely nem elég sokoldalú, nagyon kevés információn alapul, és lényegében kizárja magát a tanárt a saját teljesítményével kapcsolatos diskurzusból.

- Az értesítési idő drasztikus lerövidítését elsősorban azért kifogásolják a szakszervezetek, mert félö, hogy a napjainkban még fontosabbá váló iskolai önértékelés - amelynek az iskolai élet minden területét fel kell ölelnie naprakészen tartása túl nagy tehet fog róni az iskolavezetésre és a tanárokra. Úgy vélik, hogy az önértékelés legfontosabb funkciójának a fejlödés elősegítését kellene tekinteni, nem pedig a tanfelügyeleti igények kielégítését.

- A szakszervezetek tartanak attól, hogy túlságosan meg fog nőni a pár perces óralátogatások száma (már érkeztek is ilyen jellegü panaszok a szakszervezethez), pusztán azért, hogy ne kelljen a felügyelőknek visszajelzést adniuk (25 percnél rövidebb óralátogatás után ugyanis az előírások szerint ez most nem feltétlenül szükséges). A szakszervezet azt követeli, hogy minden látogatás után legyen kötelezö a visszajelzés.

- Szintén problémát látnak a szakszervezetek abban, hogy az új kormány kevésbé akarja figyelembe venni a különböző iskolák kedvezöbb vagy ked- 
vezőtlenebb kontextusából fakadó különbségeket, mondván, hogy ezeknek a különbségeknek úgyis csökkenniük kell. (Ugyanis áttértek az ún. hozzáadott érték alapú - ún. CVA súlyozásról - a RAISEonline alapú eredményértékelésre, amely kisebb súllyal veszi figyelembe a hozzáadott értéket.) Ezt az érvet a szakszervezetek ugyan elfogadják, azonban hangsúlyozzák, hogy számos olyan tényezö létezik, amelyekre az iskolának nem lehet semmiféle befolyása, tehát ezeket nem lenne igazságos teljesen figyelmen kívül hagyni.

- Az egyik legsúlyosabb veszélynek a szakszervezetek a Szülői vélemények (Parent View) online kérdőív felhasználását látják, mert nem látják biztosítva, hogy az oda beérkező adatok csak olyan személyektől fognak származni, akik valóban jogosultak véleményüket kifejteni az adott iskolával kapcsolatban. Aggodalmaikat fejezték ki a szülöi panaszok kezelésével kapcsolatban is, különösen a kisebb jelentőségi ügyekben tett panaszok központi nyilvántartása miatt.

- Tartanak a szakszervezetek attól is, hogy amennyiben az iskola a „nem megfelelő" kategóriába kerül, rettenetesen erős nyomás várható az iskolafenntartó és az iskolavezetés részéről, amelynek következménye az értekezletek, a belső óralátogatások és a különböző bürokratikus követelmények szélsőséges megszaporodása lehet.

- Problémái vannak a szakszervezetnek az újonnan bevezetett „fejlesztést igényel" kategóriával is, mert úgy érzik, hogy ezzel az Ofsted ismét (mint ahogy 2009-ben) változtatott a mércén, ami tovább fogja növelni az iskolákra nehezedő nyomást, aminek végső soron megint a tanárok fogják meginni a levét.

\section{Összegzés}

Az angol rendszer legfontosabb vonásai tehát a következő címszavakkal foglalhatók össze:

A rendszer...

- célja egyértelmüen az, hogy elősegítse az oktatás színvonalának fejlesztését, és hogy az oktatás intézményeket legalább a ,jó iskola" minimális követelményeinek való megfelelésre sarkallja, illetve, hogy a legjobbakat az elért színvonal hosszú távú fenntartására ösztönözze;

- filozófiájában az alapegység az iskola egésze, a fenntartótól az iskolaszéken, az igazgatón, a tágabb értelemben vett iskolavezetésen át a tanári karig és a kisegítő személyzetig. Ennek megfelelően fókuszában az iskola mint intézmény, nem pedig az egyes személyek teljesítményének megítélése áll; 
- az egyes tantárgyak tanításával kapcsolatos „,részletkérdéseket”, azaz a szaktárgyi felügyeletet elkülöníti az iskolai munka egészére irányuló tanfelügyelettöl;

- az egyes tanárok munkájának értékelésével, az egyéni munka minősítésével és fejlesztésével és az egyén előmenetelével kapcsolatos „,személyekre vonatkozó" teljesítményértékelést elkülöníti az iskolai munka egészére irányuló tanfelügyelettől és a szaktárgyi felügyelettől is;

- a lehető legnagyobb nyilvánosságra és átláthatóságra törekszik mind a felügyelet lebonyolítását, mind pedig az eredmények hozzáférhetőségét illetően;

- hatásos és hatékony, mert a kulcsterületek kijelölésével az iskola „központi idegrendszerére", az intézményi munka minőségét leginkább meghatározó tényezők vizsgálatára koncentrálja az erőforrásokat, miközben nyitva hagyja a lehetőséget arra, hogy az ezeken a területeken kívül eső információk is befolyásolhassák a minősítéseket;

- az adatok begyüjtését a lehető legszélesebb, gyakorlatilag korlátozás nélküli forrás-körre hagyatkozva végzi, az iskolára vonatkozó mérési és statisztikai adatoktól (például a tantervi szakaszok végén esedékes sztenderdizált tesztek) kezdve, az óralátogatásokon, a dokumentumelemzéseken (iskolai pedagógiai program, iskolai önértékelés stb.) keresztül a személyes (igazgatói, tanári, szülői, tanulói stb.) adatközlésig és az on-line kérdőívek felhasználásáig;

- $\quad$ szigorú protokoll szerint, nyilvános és egységes tematikával, módszerekkel és mérőeszközökkel, sztenderdekre alapozott szempont- és minősítő rendszer alkalmazásával biztosítja az objektivitást és az egyenlö eljárásmódot a különbözö iskolák esetében, ezért kiszámítható;

- minden minősítő döntését konkrét, dokumentált bizonyítékokkal alátámasztható módon és a felügyelet összes lebonyolítójának kollektív egyetértése alapján hozza meg;

- minősítő döntéseit rendkívül egyszerüen, egyértelmüen, bárki számára érthető formában fogalmazza meg;

- nem csak magukat a minősítéseket közli, hanem részletes útmutatást ad az egyes területeken tapasztalt hiányosságok kijavításával kapcsolatban is, valamint rendszeresen ellenőrzi az erre irányuló későbbi iskolai erőfeszítéseket;

- $\quad$ az elért eredmények alapján ésszerüen, szelektív rendszerességgel szervezi a vizsgálatot: az alapnak tekintett, a többséget képviselő, ,jónak” minősített iskolákra vonatkozó ötévenkénti ellenőrzésnél a legjobb iskolák esetében kevesebb (akár a felügyelet alóli teljes mentesítésig terjedő) figyelmet szentel, míg a problematikus intézményekre sokkal több erőforrást fordít (gyakoribb ellenőrzések mindaddig, amíg előrelépés nem tapasztalható), 
miközben gondot fordít arra is, hogy ne fosszilizálódjanak a kiváló minősítések sem (kötelezö és rendszeres „kockázati elemzések”);

- nehezen kijátszható: a látogatásra nem lehet a szó rossz értelmében „felkészülni” - erre sem idő, sem mód nincs;

- hatékony és jól szervezett, a minisztériumtól független (közvetlenül a Parlamentnek jelentő), de azzal szorosan együttműködő intézményi háttéren alapul, amely megfelelő költségvetési forrásokkal rendelkezik a munka magas színvonalú ellátáshoz;

- a költséghatékonyabb müködés érdekében egészséges egyensúly van a föállású és a mellékállású felügyelők számában. Mindkét esetben gondosan - de nem mechanikusan, pusztán végzettségek alapján, hanem inkább az alkalmasságra és a tapasztalatra koncentrálva - választják ki a szakembereket, valamint gondoskodnak kiképzésükről és rendszeres továbbképzésükről is.

\section{Irodalom}

BBC News (2010): More schools are failing Ofsted checks. http://news.bbc.co.uk/2/hi/uk_news/education/8559402.stm

Crown copyright (2005): Ofsted - Subject and survey inspection. http://education.staffordshire.gov.uk/

Crown copyright (2006): Ofsted - School inspection: an evatuation. https://www.education.gov.uk/publications/eOrderingDownload/evaluation_2373.pdf

Crown copyright (2011): Ofsted - Risk assessment of maintained schools and academies $\mathrm{http} / / / \mathrm{www}$.ofsted.gov.uk/resources/risk-assessment-of-maintained-schools-and-academies

Crown copyright (2012): Teaching Agency - Teacher misconduct - Information for teachers. https://www.education.gov.uk/publications/eOrderingDownload/teacher\%20misconduct $\% 20$ information\%20for\%20teachers.pdf

Crown copyright (2012/b): The Education (School Teachers' Appraisal) (England) Regulations 2012. http://www.legislation.gov.uk/uksi/2012/115/made

Crown copyright (2012/c): Department for Education - Teachers' Standards, 2012 May. https://www.education.gov.uk/publications/eOrderingDownload/teachers\%20standards.pdf

Crown copyright (2013/a): Ofsted - School Inspection Handbook. http://www.ofsted.gov.uk/resources/school-inspection-handbook

Crown copyright (2013/b): Ofsted - The Framework for School Inspection. http://www.ofsted.gov.uk/resources/framework-for-school-inspection

Crown copyright (2013/c): Ofsted - Guidance on the use of evidence forms. www.ofsted.gov.uk/resources/090156

Gilbert, C. (2009): Letter from Christine Gilbert, dated 6 July 2009, Parliamentary Debates, House of Commons, 9 July 2009, column 997W.

http://www.parliament.the-stationery-office.co.uk/pa/cm200809/cmhansrd/cm090709/ text/90709w0019.htm 
HMSO (2006): The Education [School Teacher Performance Management] [England] Regulations 2006. London: The Stationery Office. http://www.legislation.gov.uk/uksi/2006/2661/contents/made

Király Zsolt (2011): A tanári teljesítmény értékelése és a tanárok előmeneteli rendszere az angol közoktatásban. In: Falus Iván (szerk.): Tanári pályaalkalmasság - kompetenciák - sztenderdek. Nemzetközi áttekintés. Eszterházy Károly Föiskola, Eger, 25-46.

Király Zsolt (2013): Tanártovábbképzés Angliában. In: Falus Iván (szerk.): Pedagógustovábbképzés - Nemzetközi áttekintés. Líceum kiadó, Eger, 79-138.

NASUWT (2012): Ofsted inspection from September 2012 - Guidance for Teachers. www.nasuwt.org.uk/consum/.../nasuwt_009948.pdf

Ofsted (2010): Ofsted Resource Accounts 2009-2010, Office for Standards in Education, Children's Services and Skills. 2010-07-22, retrieved 2010-12-1

http://www.ofsted.gov.uk/resources/ofsted-resource-accounts-2009-10

Sinka Edit (2008): Az OFSTED brit tanügyi felügyelet müködése. TÁRKI-TUDOK www.tarki-tudok.hu/file/kerekasztal/ofsted.pdf 